\title{
Metaphorical Expressions in the Book Ngawur Karena Benar by Sujiwo Tejo: A Pragmatic Approach
}

\author{
M. Arif Rahman Hakim \\ arifelsiradj90@gmail.com \\ State Institute of Islamic Studies (IAIN), Bengkulu \\ Jl. Raden Fatah, Pagar Dewa, Bengkulu, Indonesia
}

Sabila Medina

medinasabila@gmail.com

Brawijaya University, Malang

Jl. Veteran, Ketawanggede, Lowokwaru, Malang, Jawa Timur, Indonesia

Received: January 5, 2017; Accepted: February 23, 2017; Published: March 3, 2017

\begin{abstract}
This study concerns on metaphorical expressions in the book Ngawur Karena Benar written by Sujiwo Tejo and their nonliteral meaning. In finding the metaphorical expressions, researchers used the theory of metaphor. Otherwise, in analyzing the nonliteral meaning, it was used relevance approach. According to relevance theory, the process of interpreting a metaphorical expression comprises the following steps: decoding the linguistic input by arraying possible meanings of an utterance and drawing inferences by taking into account both the results of linguistic decoding. The problems are to answer: 1) what metaphorical expressions can be found in the book Ngawur Karena Benar by Sujiwo Tejo, 2) what are the meanings of the metaphorical expressions used in the book. This study applied qualitative research method by employing document analysis approach to get detailed data description from the object analysis. Results of this study revealed that the metaphorical expressions are used to deliver a complicated circumstance in revealing the real condition. In line with the finding, the nonliteral meaning of the metaphorical expression needs an intralinguistic that is the information we can receive by decoding the linguistic input while the extralinguistic factor is the assumptions taken from context by drawing inferences.
\end{abstract}

Keywords: metaphor, book ngawur karena benar, pragmatic approach

Journal on English as a Foreign Language, 7(1), 17-34

Copyright @ 2017 by JEFL, p-ISSN 2088-1657; e-ISSN 2502-6615 


\section{Arif Rahman Hakim \& Sabila Medina}

How to cite this paper: Hakim, M. A. R., \& Medina, S. (2017). Metaphorical Expressions in the Book Ngawur Karena Benar by Sujiwo Tejo: A Pragmatic Approach. Journal on English as a Foreign Language, 7(1).

According to Argente and Payrató (1991, p. 467), understanding pragmatics in a very general sense, simply as the study of language use, we should be concerned, as well as in sociolinguistic analysis, with: (a) macro-sociolinguistic processes of maintenance and shift, (b) the emergence of contact varieties attached to specific social groups (pidgins, L2 vaneties), and (c) micro sociolinguistic processes of interaction, where particular language choices are manifested (for instance, code-switching). If we understand pragmatics in a more traditional restricted sense, as the study of language usage as it is produced by languages users, the pragmatic approach give entrance to the subjects in our analysis of linguistic facts, that is to say, it interprets these facts taking account of the speakers' values, attitudes, and goals. Although this conception is mainly oriented towards microsociolinguistic processes, it further allows us to conceive of macrosociolinguistic processes as the result of the speakers' cumulative choices and actions. Taken like that, language maintenance and language shift may be viewed as a consequence of the adaptation of some groups of users to changing sociocultural circumstances through language use continuity or disruption.

Generally, pragmatic approach is an approach to literary criticism that shows reader's impressions towards literature work at a certain period of time or era. Whereas according to competent experts, pragmatic approach is defined as follows. First, Teeuw in 1994 defined pragmatic approach theory as a knowledge of pragmatic study in the literature that stresses the reader's dimension as a catcher and giver on the meaning of literature work. Second, Relix Vedika in Poland defined pragmatic approach as like artifacts which being resurrected by the reader as a concrete process. Third, Dawse and User in 1960 defined it as the reader's intervention to literature work determined by known as "Horizon Reception" that affects on literature itself.

This kind of approach adheres to the principle that good literature is providing enjoyment and theorem for the reader. Therefore, it combines the elements of solace and didactic. The utilization of this approach has to deal with the relativity concept of magnificence and didactic value. Every generation in any era required to tell this magnificence value. But it does not mean the interpretation is a mere subjective.

The structural approach cannot do much about the effort to help one capturing and giving signification on literature work. Another aspect even 
needed to explain literature's meaning in a better way. Thereupon, experts purpose a new approach called pragmatic approach.

With the emergence of this approach, then appears the study to reader's role as a subject that always changes under circumstances. It is not enough only to research the autonomous literature, but the researcher has to go through the process of giving significance. Literature context at the end is a broad social context.

Literature has an objective structure that gives a room for the reader. But, this room is not suitable yet. It needs the concrete process which is objective to allow the reader "come in".

According to Jousz, a reader's interpretation of a literature text determined by what he calls horizon reception. Every reader has this reception that might be different or same, build upon the reader's differences and assumptions. So that, literature's significances is not something last forever. There will be the time a literature gets the air because reader's stages of reading are not accordance what has been presented in the work. However, this rejected literature could be accepted by another reader because their horizon reception is being fulfilled by the work.

The relation between the reader and the text of literature is relative. The work of literature always presents something uncertainty, whilst the reader must be active and creative at prescribing the significance of literature.

Referring to the history of pragmatic approach, in 1960, appeared two experts of Literature in West Germany named Hans Robert and Wolfgangler. Both of them developed a study in the literature that gave suppression to readers as "The Giver" for literature's meaning.

Teeuw (1984, p. 5) said that historical research in Europe has long been deadlocked. This is because the approach to the writing of literary history is not based on the situation at that time since Romantic era. With the concept of nationalism, the approach to the writing of literature history is aligned as national history and the other approach which is not considering the dynamic of literature continuous use.

What a reader accepts and understands have great influences to the next literature work, both in terms of aesthetics and history. Literature is an art aesthetically, the reader will decide whether the beauty of the work is accepted or the opposite. Thereof, the emphasis in this approach underscores the reader's role as "The Giver" is not the timeless beauty towards a work of literature, but the acceptance of the work itself in different times and places.

The main character in Literature that accentuates reader's role is Hans Rober Jauss as he wrote in his papers entitled "Literature History as a Challenge to Literary Theory". He staged many new thoughts that once 


\section{Arif Rahman Hakim \& Sabila Medina}

shocked the world. Traditional Literature study after giving the summary about Literature History among others is from the flow of Marxism and Formalism. To eliminate the most important thing in the process of semiotic called Literature, and its attitude of communication which describe the dialog's relationship between the reader and the work, e.g.: readers who assess, interpret, understand, and relish the literature to determine its fate and role in terms of history and aesthetic.

The Literature History researcher has a job to explore the reception of literary works of all time, the magnificence is an understanding that depends on situation and background of reader's socio-cultural and the Literature study needs to particularize it.

Basically, language is a human system of communication that uses arbitrary signals, such as voice sounds, gestures, or written symbols. Besides language as a human basic system of communication, it is an art. Beautiful language could trigger people imagination in realizing the text read. In nonscientific writings (poetry, short story, novel, film script, song, etc.), beautiful language is often used to make people, as language users (speaker, writer, reader, listener) understand the meaning to minimize misunderstanding. What is meant by beautiful language is a spoken or written form which uses some expressions of figurative language. So, non-scientific writings use the expressions of figurative language to deliver certain meaning or message.

'Beautiful language' can also mean 'implicit language' because 'implicit language' deals with nonliteral meaning. To create implicit language, the writer needs to understand figurative language. One of the mostly used figurative languages is a metaphor. It was observed that metaphor is fundamentally a kind of mental mapping and neural coactivation from which certain patterns of conventional and which influences how people think, reason and imagine in everyday life (Lakoff 2008; Lakoff \& Johnson cited by Tendahl, 2009, p. 114). However, the metaphorical expression is strongly tied with our daily lives. In commercial advertisements, books, poetry, poems, newspapers, and many others, metaphorical expression appears to provide a strategic way in order to deliver certain messages. "Metaphor is (elliptic) similes or comparison statement. Metaphorical meaning is the form of 'a is (an) F'." (Stern, 2000, p. 229). The metaphor is representative of a single natural kind of figurative language since it does not use a grammatical requisite like 'like' in simile or a specific name which is associated with something related to. It carries such interpretation more naturally than other statements of comparison.

In analyzing metaphorical expressions, the writer uses relevance theory approach. The Relevance theory approach sees truly pragmatic inferences not only in the implicit parts of the language, but also in its explicit parts. The 


\section{Arif Rahman Hakim \& Sabila Medina}

nonliteral meaning of the metaphorical expression that is analyzed with this approach is gained by the process of pragmatic representation of the utterance. Furthermore, finding the implicit and explicit meaning is the important step to catch any possible meaning in a metaphorical expression by decoding the linguistic input. Pragmatics is the important step of analysis process in nonliteral meaning by drawing inferences. Thus pragmatics in relevance theory provides definition and method on how to analyze the nonliteral meaning in metaphorical expressions. The analysis is limited to the nonliteral meaning of the metaphorical expressions.

Studies of metaphor have taken on an absolutely new look ever since 1980s, evidenced by Metaphors We Live by collaborated by Lakoff and Johnson cited by Tendahl (2009) which has rocked to the core studies of metaphor in linguistic field, attributing to their interpretation of metaphor system in the line of cognition named modern metaphor and proposes that metaphor is a matter of thought and action rather than a device of poetic imagination and the rhetoric flourish. Kovecses (1986) presents a demonstration that emotions such as anger, pride and love are conceptualized structure in everyday language. All these studies illustrate the cognitive idea of metaphor, i.e. metaphor mediates human understanding and world view (Lan, 2005).

The book Ngawur Karena Benar by Tejo (2012) tells the condition of Indonesia from the aspects of the economy, socio-culture, the basic principle of Indonesia, low quality of human resource, and other aspects. In this book, he interprets the problems found in Indonesia uniquely. He teases those issues by insinuation and allusion using a story from pewayangan, using puppetry names instead of the names of the real actors. This book is a collection of his writings in various national mass media. What makes this book special to be analyzed is the existence of the object matter variety of linguistic branches study.

This study is expected to be beneficial for enriching teaching material on metaphorical in context expression since the data are taken from the book which contains many metaphorical expressions. It is also expected to broaden the knowledge of linguistic students about metaphorical expressions in literary work. This research could be an important reference for students in learning metaphor expression and the meaning of interpretation because it has passed an analysis process. At the same time, it could be used as a reference for the following linguistics researchers who analyze the same topic.

Yule (1996, p. 4) stated that "the advantage of studying language via pragmatics is that one can talk about people's intended meanings, their assumptions, their purposes or goals, and the kinds of action (for example, requests) that they are performing when they speak. According to Stern (2000, p. 79), a metaphor is one of comparison statements besides simile, irony, 


\section{Arif Rahman Hakim \& Sabila Medina}

metonymy, synecdoche, meiosis, and understatement. The metaphor is made between things which are essentially not alike. It is similar to a simile, but does not use 'like' or 'as'. Furthermore, Stern (2000, p. 80) argues that metaphor is representative of a single natural kind of figures. In expressing a statement, the metaphor is in the form of ' $a$ is (an) $\mathrm{F}^{\prime}$ to deliver a literal meaning of ' $a$ like (an) $F^{\prime}$. The metaphorical expression does not merely show itself as a metaphor but the readers or the listeners know that, that the metaphorical expression contains such metaphorical meaning. An example of a metaphorical expression is "I love my family more than I love myself". The first idea popped up in the interpreter's mind must be "I love myself more than anything" or "Human beings are born as individuals who are competing to achieve their wishes so, in other words, human beings are creatures of ego-centric, then it is not even close to love other people more than myself". Then, the nonliteral interpretation is going to be, if there is someone who loves his family or other people more than he loves himself. Then he really loves his family so much. Even he would put the interests of his family first then his own interests.

Related to the characteristics of metaphor, different perceptive metaphors certainly do not perform independently, as Lakoff and Johnson cited by Tendahl (2009) placed, metaphorical entailments classify coherent system or the concepts of metaphorical and a compatible coherent system of metaphorical phrase for those construct. In English, there are three metaphors related to time, namely,

Time is money

How do you spend your time these days?

That flat tire cost me an hour.

Time is a limited resource

You don't use your time profitably.

You are running out of time.

Time is a valuable commodity.

I don't have the time to give you.

Thank you for your time.

(Lakoff \& Johnson cited by Tendahl (2009)

Knowledge of what money, restricted resources and worth commodity are in mind, these metaphors can simplify our fathom of the abstract drought time. The three metaphors greatly agree to each draft and as the whole, they unite into a harmonious, for money is in modern people a finite source while a limited resource is a commodity.

In the linguistic system, Metaphor endures a prolongation and new meaning of words, as well a trestle of the familiar and unfamiliar. A semantic domain map onto another is created by Metaphor (Lakoff \& Turner, 1989). 


\section{Arif Rahman Hakim \& Sabila Medina}

The procuration of new lexical meaning is produced by cognitive semantics which is by no means footless and is grounded on the cognitive structuring that establishes different significances of one word connect to each other in a rational way. A polysemy lost can be used to elucidate Sweetser's stand. We could define the meanings of word loud as follow (a) having the substantial intensity of sound, (b) generating a major intensity of sound; resounding (c) vehement or dauntless: strong denunciations. (d) insipidly bright; flashy, striking: a loud red automobile (e) obsessive in mien or manner: Robert is a big mouth, pervert person (Macmillan contemporary dictionary). The literal meaning and slight distinction appear to be the first two items, while the third item is somewhat different from its literal meaning yet still endures imminent intercourse to sound item four and five bears no lineal connection to sound, but still, repress from high- pitchingness and ear-catchingness of sound. Metaphorization is the effective mechanism to create potential connotation.

Related to the case above, Fachun \& Hu stated that the writers want to select them three to remain on, for all its features. They are potency of enriching semantic meaning, structured character, and universality.

The metaphor is not merely parturient to linguistics but also has incorporated into and become the highlight of the sphere in philosophy cognitive science, sociology, education, and artificial intelligence. Philosophers have been enamored by this metaphor in a terrific attention, which is indicated by Kant's elaboration on a conceptual metaphor from the angle of construction and exhibiting that our language is full of Metaphor's conceptualized expressiveness implicitly deriving from itself.

In 1960, German philosopher Blumenberg also denoted with emphasis that most of the consideration of human beings is metaphorical because of scholarly account and abstract can be feasible. Metaphor multiplies are so much in the nature of science. For example, in physics, we happen to know what is electricity is in the parlance of understanding the inexplicable water we are prevalent with, according to expressions of electricity's stream down, tension, detention, to name just a few. Metaphor, used in our daily thinking and acting as an omnipresent fundamental of human languages and makes abstraction possible, thereupon it is a must to think in metaphor. Lackoff and Johson's research indicated the even higher frequency of the use of metaphor $-70 \%$ of expressions in language derived from metaphorical constructs. Ortony (1929) said that all languages are metaphorical quality "The principle of relevance applies without exception: every act of ostensive communication communicates a presumption of relevance." (Sperber \& Wilson, 1986, p.161).

In interpreting the nonliteral meaning of metaphorical expressions, relevance theory proposes two combinations of both logical form and Journal on English as a Foreign Language, 7(1), 17-34

Copyright @ 2017 by JEFL, p-ISSN 2088-1657; e-ISSN 2502-6615 


\section{Arif Rahman Hakim \& Sabila Medina}

inferential methods. The first process is what constitutes logical form. It is the set of assumptions the subject in a metaphorical expression which the communicator intends to make manifest to the addressee is relevant enough to make it worth the addressees. That concerns with information received by decoding the linguistic input, or in other words, we array any possible meanings of a metaphorical expression. The second process is an inferential process, drawing inferences by taking into account both the results of linguistic decoding, i.e. the logical form, and assumptions taken from context. Addition information about the method is quoted below.

"A good creative metaphor is precisely one in which a variety of contextual effects can be retained and understood as weakly implicated by the speaker. In the richest and most successful cases, the hearer or reader can go beyond just exploring the immediate context and the entries for concepts involved in it, accessing a wide area of knowledge adding metaphor of his own interpretations of possible developments" (Sperber and Wilson, 1986, p. 236).

The book Ngawur Karena Benar which was published in 2012 by Imania Publishing is a collection of Sujiwo Tejo's writings in the various national mass media. It consists of thirty-seven chapters and two hundred and fifty-seven pages. Telling about the current issues in Indonesia in a unique way, he teases those issues by insinuation and allusion by using the name of puppetry names as the name of the actor in the book. The aspects of the economy, socio-culture, the national anthem of Indonesia, low-quality human resource, and some others are the concerning topic that he criticizes in the Ngawur Karena Benar. What makes this book special to be analyzed is the existence of the object matter variety of linguistic branches study.

\section{METHOD}

This conducted research is a qualitative research by employing document analysis to get detailed data description from the object analysis. The data description the writer used the theory of Creswell (1998) as a guidance to this research method.

In collecting the data, the writer absolutely had to use the right method in order to get the accurate data. To validate the data and the result of interpretations of the metaphorical expressions, the writer used peer checking method. Lincoln and Guba cited by Utami (2012) considered member checking are a particularly important technique for establishing the credibility of qualitative data. In a member check, the writer provided feedback to study participants about interpretations and obtain participants reactions. The argument was that to assess whether the writer's interpretations were right representations.

Journal on English as a Foreign Language, 7(1), 17-34

Copyright (C) 2017 by JEFL, p-ISSN 2088-1657; e-ISSN 2502-6615 


\section{Arif Rahman Hakim \& Sabila Medina}

The checkers are mentioned as follow; Mahrus Ali Hasan, Muhammad Arif Elsiradj. They were chosen because those linguistic master colleges have a good understanding in pragmatics, proved by the scientific journal in linguistics field they made and they considered giving a good contribution in checking the research. There were three phases of data collection that the writer used, mentioned as follow:

1. Reading the book.

2. Identifying the metaphorical expressions based on Metaphor theory (Stern, 2000), the list of chapter and page of each metaphorical expression, and the context that might relevant to the metaphorical expressions based on Relevance theory (Sperber \& Wilson, 1982).

3. Putting the finding into the following form to make the analysis easier by looking right to the form.

Table 1. Data Form

\section{Data Form}

1. Chapter

2. Page

3. Metaphorical expression

4. The context

After the data was complete, the writer started to analyze the data. The steps were mentioned below:

1. Finding a range of contextual effects which can be retained as weak or strong implicatures.

2. Adding them to the overall interpretation of the metaphorical expression until it is relevant enough to be consistent with the principle of relevance.

3. Interpreting the nonliteral meaning of the metaphorical meaning based on the context by the cognitive thought of the researcher.

4. Drawing conclusion from the analysis.

\section{FINDINGS}

In this part, the researchers found sixteen metaphor expressions from Book Ngawur Karena Benar who written by Sujiwo Tejo.

(Data 1) Dia menjadi serbacacat penuh bilur berupa Panakawan Gareng; he became full-round defects in the form of Punakawan Gareng.

(Data 2) "Saya iri ke Menak Jinggo .... Hidup luntang-lantung bagai gelandangan di bawah pohon tapi hatinya penuh cinta. Kami hidup enak di ruang AC, bergemilang duit, tapi cinta kami redup, bahkan kering kerontang," ungkap seorang anggota dewan; "I envy Menak Jinggo ... living like a wandering homeless 


\section{Arif Rahman Hakim \& Sabila Medina}

person under a tree but his heart is full of love. We live in an air-conditioned room, have much money, but our love is dim, even parched," said a legislative member.

(Data 3) "Dayun: cinta itu takdir, menikahi itu nasib"; Dayun: love is fate, to marry is destiny).

(Data 4) Cinta itu ajaib, datang dan perginya tak dapat kita rencanakan.; Love is a miracle, as it comes and go unpredictably.

(Data 5) Harusnya kesabaran itu seperti keinginan, tak ada batasnya.; Patience should be like a wish, no limit in it.

(Data 6) Sosoknya yang semula bagus menjadi bonyok-bonyok berbentuk Panakawan Petruk; the former good figure becomes black and blue as Punakawan Petruk.

(Data 7) Bu guru kerap bercerita betapa Merah-Putih merepresentasikan ekspresi merah dan putih di berbagai daerah sejak tajin sampai ragam hias, sejak dulu sampai sekarang.; the teacher used to tell how the color of Indonesian flag, red and white represents the expression of red and white in various regions fromtajin to ornaments, from the beginning until now).

(Data 8) Lagu kebangsaan (sekali lagi baca: hal musikal seperti juga hal-hal musikal yang dibisikkan sejak janin hingga liang lahat) adalah urusan emosional; national anthem is a music like other music that is being whispered to the fetus to the dead. It is a matter of emotion.

(Data 9) Menjadi suami atau istri yang gagal kerap dinilai tak menjaga kehormatan keluarga besar.; being a failed husband or wife is often considered as not keeping the family honor.

(Data 10) Jika kegagalan adalah sukses yang tertunda, berarti bisa kita harapkan kebohongan adalah jujur yang tertunda; if failure is apostponed success, we could hope that a lie is a postponed honesty.

(Data 11) Tapi Cepot tetap merasa akan sanggup menggenggam angin; However, Cepot was still sure that he could grasp the wind.

(Data 12) Ternyata Resi Palarasa masih kalah sakti dibanding pegadaian; apparently Resi Palarasa is still less powerful compared to the pawnshop.

(Data 13) Keadaannya kini jauh bumi dari langit....; the condition now is very contrast as which is like the earth and the sky.

(Data 14) Bedanya, dengan suatu negeri di bumi, di negara itu banyak orang malu memakai simbol Sengkuni, tapi kelakuannya Sengkuni sekali; it's different with a country on earth. In that country, many people are embarassed to wear the symbol of Sengkuni, but their behaviour is like Sengkuni.

(Data 15) Hanya orang sinting sekarang yang memegang teguh satunya kata dan perbuatan.; only insane people who believe that his word should be reflected on his deed. 


\section{Arif Rahman Hakim \& Sabila Medina}

(Data 16) Yaitu, mereka lebih rendah dibanding rakyat yang sudah rendah; they are more abject than citizenry. "They" refers to Legislative Assembly of Indonesia. The legislatives should be aware of their duty as the servant of the people, rather than betray the folk by using state money to tour overseas. Besides, as we often saw in media, many board members were involved in corruption cases, and also a number of board members slept or ignored the meeting. They were supposed to be on duty to support the folk's rights and demand instead of abusing their position. It could be said that parliament members were lower than the people who chose them as their leaders.

\section{DISCUSSION}

In this part, researchers discuss and explain the interpretation of the metaphor expressions was provided. The interpretation was nonliteral meaning so then extralinguistic factor was involved because it was very important.

(Data 1) In the story, Bambang Sukskati who played the role of Jaka Umbaran, came to Banyuwangi to kill Kebo Marcuet in order to fight for Kencono Wungu to be married by Jaka Umbaran. Unexpectedly, Kebo Marcuet was much stronger than Jaka umbaran. Then Bambang Sukskati as Jaka Umbaran lost the fight and was disfigured. The sentence was the comparison of Bambang Sukskati to Panakawan Gareng. The keyword was the word 'in the form of'. From the sentences carrying the context, the writer found that "he" refers to Bambang Sukskati who was beaten up by a knight from a neighboring village. In the world of puppetry, Panakawan Gareng was figured as a disabled person who had a broken nose, ape eyes, fat belly, crooked arms and was lame. Thus, the comparison of Bambang Sukskati to Panakawan Gareng meant that Bambang Sukskati was battered on many parts of his body and were as ugly as Panakawan Gareng.

(Data 2) The story told that another competitor to get Kencono Wungu's love was Menak Jinggo. Menak Jinggo was successful in beating Kebo Marcuet and was one step closer to marry Kencono Wungu. But when the time to marry Kencono Wungu came, she did not want to marry him. The full-of-love heart of Menak Jinggo was hurt. He was really disappointed. Then the point that the author wanted to emphasize was the richness of love of Menak Jinggo was more than those of the legislative members although they were wealthy. That sentence referred to the real condition of the legislative performance, many of the legislatives misconducted behavior such as corruption. It was compared to Menak Jinggo who was a full-of-love person to people around him even when he was poor. On the contrary, the legislatives did corruption although they were wealthy. In other words, legislatives as the representatives of people 


\section{Arif Rahman Hakim \& Sabila Medina}

should fight for the benefit of the people they represented but there were many corruption cases they did. And that undermined public trust to the legislative parliament. In relation to the sentence, legislatives did not have love in their heart.

(Data 3) The metaphor expression was the comparison of the love problem of Menak Jinggo and Kencono Wungu. The disappointment experienced by Menak Jinggo could be used as a lesson for us. In human love's problem, when someone we love did not accept our love, our crush could not be blamed because love feeling could not be resisted or created intentionally. On the other hand, to marry someone was a fate. It meant that everybody was allowed to propose anybody who he loves, but whether he or she accepted our love was outside our control. It belonged to God's provision.

(Data 4) The metaphor expression was compared to the love problem experienced by Damarwulan. In the story, Kencono Wungu's love to Damarwulan caused her to reject Menak Jinggo's love and in turn, it made Menak Jinggo really hurt. Menak Jinggo should not be angry or sad so bad by because basically love was a magical one which came and went unexpectedly and could not be expected or set by anybody. Love to someone could not be planned before and so did love answer. Sometimes, the hope of love was ignored or rejected. Then, the only thing human could do was keep fighting for love and be patience in the process.

(Data 5) In the story, Menak Jinggo was very angry due to the rejection from Kencono Wungu. Thus, the sentence was the representative of Menak Jinggo's love problem. As we know, mankind always wanted a better thing than what they had and it continued until they died. Men always tried to reach their goals, even sometimes in bad ways when they failed. Thus, we needed the patience to face failure. In other words, failure must always be there accompanying us along the road to success. Thus, patients should always exist in human's heart like human never-ending desire. Then, they had to replicate it in the real life.

(Data 6) Menak Jinggo was compared to Panakawan Petruk. In context, Damarwulan was beaten up by Menak Jinggo because of the romance problem. Because of Menak Jinggo's great anger, the fight between Menak Jinggo and Damarwulan caused Damarwulan's body battered similar to the figure of Panakawan Petruk in puppetry. Panakawan Petruk was portrayed to have a disfigured body and facial defects.

(Data 7) In context, the color of Indonesian national flag, red and white, were used by many ethnic groups in many things from tajin, a traditional food from Java or traditional dresses to traditional arts. It existed since a long time Journal on English as a Foreign Language, 7(1), 17-34

Copyright $@ 2017$ by JEFL, p-ISSN 2088-1657; e-ISSN 2502-6615 


\section{Arif Rahman Hakim \& Sabila Medina}

ago until now. Both red and white meant pure. The red color was similar to the color of Javanese palm sugar and white color was similar to the color of the rice. Both were the main ingredients in Indonesian cuisine, especially in the island of Java. When the Majapahit empire triumphed in the archipelago, the color of the banner used were also red and white. In the past and even today, the color of red and white wore by the Javanese people to ritual ceremonies for a seven months old baby. The ritual was represented in the form of red porridge. The color of Indonesian flag had been right and precise because it represented the culture of Indonesian people.

(Data 8) The National anthem was a sensitive thing, like human emotion. Emotion, as we felt in life, was something dynamic, it always changed according to the situational condition. Thus, a song or in this context, the national anthem was compared to emotion. Tejo in his book stated,"I am worried that Indonesian people never really compact because the national anthem is not really accommodated the national collective expression." It was reinforced by the research of Harry Roesli, a Doctorate in music. He emphasized that the possible answers why Indonesian people were less reference when singing Indonesia Raya because he found dozens of weakness in the song Indonesia Raya, such as the syllable error suppression on the basis of beats and tones progression. People had to stress the intonation of the syllable "sia" in the word "Indonesia". Whereas, in official Indonesian language, the pressure on the word of four syllables fell on the third syllable of "ne". In conclusion, the song Indonesia Raya was failed to unite Indonesian people because of its musical thing mistakes.

(Data 9) This sentence referred to the failure of Susilo Bambang Yudhoyono leadership in 2004 - 2012. As seen in the context, marriage was similar to government. While the husband or the wife referred to President Susilo Bambang Yudhoyono. Furthermore, religion leaders noted and published that he had eighteen lies in the realization of several of his promises during his campaign. Surely, Yudhoyono could not accept the term used by the religion leaders that dropped his prestige as the first person in Indonesia. To respond to this news, he made a press conference to clarify what was said by the religion leaders and activists. The point of the metaphor itself was that the President should not be angry if he really made the mistakes because the statement of the religion leaders was not made by looking at the problem at glance, but by considering real evidence. Then, the author looked at this problem from the words "fail" and "lie". Yudhoyono was angrier when people said he "fail" than he "lied". Then, the author of the book compared the anger of Yudhoyono with the sentence "As I recall, in the marriage relationship, 'to fail' is not pleasant to hear. It is better to be considered as a liar husband or wife 
rather than a failed husband or wife. Being a husband or wife who fails often considered as not keeping a family honor".

(Data 10) In the sentence carrying context, Presiden Susi referred to President Susilo Bambang Yudhoyono. The sentence was a comparison of the case of President Susilo Bambang Yudhoyono. He was noted by religious leaders as having eighteen lies in his leadership period in 2009-2012.Several of his lies are; 1) The government claimed that poverty reduction reached 31.02 million. In fact, from the poor who got raskin (beras rakyat miskin) in 2010 reached 70 million of people and the recipients of health care for the poor reached 76.4 million of people, 2) President Yudhoyono launched a program of a hundred days for food self-sufficient but in early 2010, the economic hardship occurred massively, 3) President Yudhoyono encouraged breakthrough on food and energy sufficiency by developing Supertoy HL-02 dan Blue Energy program. The program failed miserably, 4) President Yudhoyono held a press conference related to Hotel JW Marriot bombings. He claimed that his picture was targeted by terrorists. It turned out that actually, the photo was old data that was shown in the first meeting with the legislative commission in 2004. He was angry when there was a news publishing his eighteen lies in his leadership period. Then he made a press conference. He should not be angry about the news because of the statement "If failure is a postponed success, thus we could hope that a lie is a postponed honesty", we had to be optimistic that there would always be a good future waiting.

(Data 11) In the story, Cepot had a girlfriend named Cangik, she lived in a different city from Cepot. Two years passed without any meeting between two those lovers. Cepot loved Cangik, although Cangikwas even uglier when compared to the ugliest person. Dawala warned Cepot that Cangik had a nature like wind that could fool people with her innocence but Cepot felt confident that he could love her forever. Thus, the word "wind" was compared to Cangik. Whatever problem hindered Cepot's love journey, he still believed that he could be always together with Cangik.

(Data 12) The slogan of the pawnshop that was "Solving problem without any problem" means that pawn shops accept pawns from people with fair regulation between the pawnshop and the people, so both sides gain profit. In the context of the metaphor expression, Resi Palarasa who was an expert in everything including medicinal treatment would like to heal Dewi Lara Amis. Yet, he was not that expert. He could not heal Dewi Lara from her illness. He made Dewi Lara's illness worse than before. Scales of skin appeared on her skin. Thus, Resi Palarasa was less powerful than pawnshop because pawnshop solved the economic problem by giving capital money or debt to people with 


\section{Arif Rahman Hakim \& Sabila Medina}

easy regulation. We just needed to pawn our valuable property then we could get the money. Then, when the period to pay back our debt comes, we could make the period longer by managing it in the pawnshop.

(Data 13) The social economic condition of Indonesia in the past was far different from contrasts to the present condition of Indonesia. Now, Indonesia was worse than it was. The metaphor tried to deliver the comparisons. The difference was that, in the past, many small traders could sell the raw material for the production at affordable price, many foreign people came to try doing business and studying, staple food was still sold at affordable price for the community. Now, even more, and more citizens were becoming Indonesian workers (TKI) in foreign countries. Other than that, the price of staple food jumped up from day to day. Increasingly more people sold their land for a business that they could not get benefit from.

(Data 14) Sengkuni was a puppet that had a bad character. He often provoked Korawa and Pandawa to fight each other. In the story, there were many foreigners who like the figure of Sengkuni regardless the character of the puppet. On the contrary, in Indonesia, where Sengkuni was born, people did not like Sengkuni to be put in their house as a wall display or accessory. Meanwhile, the metaphor expression above indicated a number of people wanted to control the country's prosperity in ways that were not good such as by collusion, corruption, and negotiation. Thus, Sengkuni as the comparison to the government of Indonesia showed that there were still many corruption cases happened here. As an evidence, the number of corruption cases increases from 2004 to 2013. In 2004 there were 23 cases and it increased to 70 cases in 2013 (www.acch.kpk.go.id).

(Data 15) The phrase "insane people" referred to the government members. The fact was a number of officials deny and did not fulfill their promises as the mandate of the people who had chosen them as the elite of the nation. To find an honest leader was almost impossible while being honest was insane. Now, an honest man was a rare thing.

(Data 16) "They" refers to Legislative Assembly of Indonesia. The legislative should be aware of their duty as the servant of the people, rather than betray the folk by using state money to tour overseas. Besides, as we often saw in media, many board members were involved in corruption cases, and also a number of board members slept or ignored the meeting. They were supposed to be on duty to support the folk's rights and demand instead of abusing their position. It could be said that parliament members were lower than the people who chose them as their leaders. 


\section{CONCLUSION}

The analysis of metaphorical's interpretation resulted in several conclusions. First, the metaphorical expression could not be separated from the situational and background knowledge context. All of the metaphorical expressions needed background knowledge or context to interpret the nonliteral meaning.

It was impossible to interpret the meaning without background knowledge which influences the writing process of the book by the author himself. Second, the function of the metaphorical expressions is to carry hidden meanings. Third, the meaning of the metaphorical expression is mostly about the issue of government work, the rest is about nationality thing. The last, the purpose of the metaphorical expression is to persuade the readers that government's work performance is bad.

\section{REFERENCES}

Akhirita, I. N. (2012). Figurative language used in public information notices in Malang. Unpublished Thesis. Malang: Universitas Brawijaya.

Argente, J. A., \& Payrató, L. (1991). Towards a pragmatic approach to the study of languages in contact: Evidence from language contact cases in Spain. Pragmatics, 1(4), 465-480.

Chun, L. (2005). Cognitive linguistics and metaphoric study. Beijing: Foreign Language Teaching and Research press.

Creswell, J.W. (1998). Qualitative inquiry and research design. London: Sage Publications.

Cummings, L. (1999). Pragmatik, sebuah perspektif multidispliner (Setiawati, Eti \& Sunoto, et al.) New York: Oxford University Press Inc.

Cutting, J. (2002). Pragmatics and discourse: A resource book for students. London: Routledge.

Hakim, M. A. R. (2012). An analysis of phonetics b, d, g, j, ds and ð into English pronunciation for Java students (a study on Java students at English department on STAIN Bengkulu academic year 2011-2012. International Journal of Humanities and Social Science, 2(20), 244-256.

Hakim, M. A. R. (2015). Experienced EFL teachers' challenges and strategies in teaching speaking for introvert students. European Journal of Social Sciences, 48(4), 437-446.

Hymes, D. (1974). Foundations of sociolinguistics: An ethnographic approach. Philadelphia: University of Pennsylvania Press

Kovecses, G. (1986). Metaphors of anger, pride, and love. Amsterdam: Benjamins 
Lakoff, G. (2008). Women, fire and dangerous things: What categories reveal about the mind. Chicago: University of Chicago Press.

Leezenberg, M. (2001). Contexts of metaphor. Netherlands: University of Amsterdam Press.

Mey, J. L. (2001). Pragmatics: An introduction (2nd ed). Australia: Blackwell Publishing.

Profil Sujiwo Tejo. (n.d.). Retrieved July 1, 2013, from http://www.sujiwotejo.com

Sengkuni profile. (n.d.). Retrieved January 1, 2013, from http://en.m.wikipedia.org

Sperber, D., \& Deirdre, W. (1982). Mutual Knowledge and Relevance in Theories of Communication. In Smith, Neil V., ed., 61-85.

Statistical Handling of Corruption. (n.d.). Retrieved January 10, 2013, from http: Kwww.acch.kpk.go.id

Stern, J. (2000). Metaphor in context. New York: Massachusetts Institute of Technology.

Tejo, S. (2012). Ngawur Karena Benar. Jakarta: Imania.

Tendahl, M. (2009). A hybrid theory of metaphor. Great Britain: Palgrave Macmillan.

Yule, G. (1996). The study of language ( $\left.2^{\text {nd }} e d\right)$. Cambridge: The University of Cambridge Press.

Yule, G. (2006). The study of language (3 $3^{\text {rd }}$ ed). Cambridge: Cambridge University Press.

Yuniariandini, A. (2013). Figurative language used in Emily Dickinson death poems. Unpublished Thesis. Malang. Universitas Brawijaya.

Zhang, F., \& Hu, J. (2009). A study of metaphor and its application in language learning and teaching. International Education Studies, 2(2), 77-81.

18 Kebohongan SBY. (n.d.). Retrieved January 3, 2013, from http://kabarnet.wordpress.com

\section{Authors' Brief CV}

M. Arif Rahman Hakim was born in Palembang, 15 December 1990. He finished his undergraduate program at English Language Teaching Program (S.Pd.), STAIN Bengkulu in 2012 and his master at the same study (M.Pd) in Islamic University of Malang (UNISMA) in 2014. He is currently working at IAIN Bengkulu as a permanent lecturer in English Language Teaching Department. Now, he is a Ph.D student of TESOL in Universiti Sains Malaysia. 
Metaphorical Expressions in the Book Ngawur Karena Benar by Sujiwo Tejo:

A Pragmatic Approach

M. Arif Rahman Hakim \& Sabila Medina

Sabila Medina was born in Sidoarjo, 17 July 1992. She finished her undergraduate program at English Literature Study Program (S.S.), Universitas Brawijaya in 2014. She is currently working at Wearnes Education Center Bali as an English trainer. 